\title{
TRANSLATOR'S ACKNOWLEDGMENTS
}

I wiSH to acknowledge gratefully the part the following persons played in the publication of this translation of Platero and I:

Allyn Gordon, now of Los Angeles, California, whose enthusiasm and active collaboration in the translation of the first eighteen chapters so long ago in Nacogdoches, Texas, gave the work its original impetus;

R. C. Stephenson, professor of English and of Romance languages at the University of Texas, who read the translation and gave invaluable suggestions for its final version;

Jaime Benitez, rector of the University of Puerto Rico, and Eugenio Fernández Méndez, acting director of the University of Puerto Rico Press, through whose efforts communication with Juan Ramón Jiménez was made possible;

Lewis U. Hanke, director of the Institute of Latin American Studies at the University of Texas, whose personal interviews with Dr. Benitez and others close to the author opened the way for contact between him and the University of Texas Press.

Austin, Texas

ELOISE ROACH

March 1, 1957 
THIS PAGE INTENTIONALLY LEFT BLANK 